\title{
Larangan Memukul Istri dalam Kajian Hadis
}

\author{
Norcahyono \\ (Dosen Fakultas Agama Islam UM Palangkarya , Alamat email: \\ norcahyono.arribangi@gmail.com)
}

\begin{abstract}
Abstrak
Penelitian ini dilatarbelakangi oleh sikap Nabi berdasarkan hadis yang di riwayat Abu Dawud tentang larangan memukul isteri. yaitu Nabi melarang suami memukul isteri, kemudian membolehkan ketika terindikasi Nusyuz, tetapi jika seorang suami bersikap ringan tangan terhadap istrinya dia bukan sosok suami yang terbaik. Oleh karenanya peneliti tertarik untuk meneliti status hadis tersebut dengan menelitinya menggunakan metode Takhrij hadis. Adapun hasil penelitian adalah sebagaimana berikut: Pertama: Hadis larangan memukul isteri terdapat dalam tiga buah kitab, yaitu: dalam Kitab Sunan Ibn Majah hadis no. 1985, Kitab Sunan Abu Dawud hadis no. 2148, dan Kitab Sunan ad-Darimi hadis no. 2219. Kedua: Status sanad hadis larangan memukul isteri yang di riwayatkan Abu Dawud sebagaimana berikut: Iyas sebagai periwayat pertama diperselisihkan tentang status kesahabatannya, namun pendapat yang lebih kuat menurut Ibnu Hajar, Ibn Hibban, al-Hakim dan adz-Dzahabi Iyas tergolong sebagai sahabi, Jika Iyas digolongkan sebagai tabi'in hadis ini berstatus mursal karena Iyas secara tidak langsung mengambil riwayat dari Nabi tanpa menyebutkan sahabat yang meriwayatkan hadis, Jika Iyas digolongkan sebagai sahabat (junior) maka hadisnya berstatus mursal sahabi, Berdasarkan 'itibar sanad dan Iyas dihukumi sebagai sahabi maka hadis ini adalah gharib, Perawi kedua sampai ke lima semuanya muttasil dan tsiqqoh, Menurut al-Bani sanad hadis ini adalah sahih.
\end{abstract}

Kata Kunci: Hadis, isteri, rumah tangga

hak suami. Ketiga, kekerasan dalam rumah tangga terjadi dalam lembaga yang legal, yaitu perkawinan.

Berdasarkan permasalahan di atas peneliti tertarik untuk mengetahui sikap Nabi melalui sabdanya bagaimana beliau menyikapi kekerasan dalam rumah tangga seperti penyelesaian Nusyuz dengan cara memukul isteri. diantara sikap Nabi adalah tercantum dalam hadis riwayat Abu Dawud pada bab $f i$ dharbi an-Nisa hadis no. 2148.

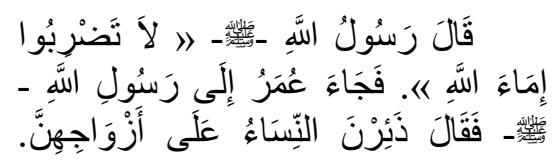

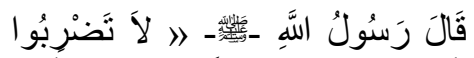

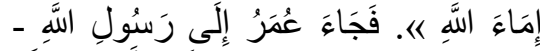

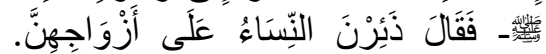

\section{A. PENDAHULUAN}

Kekerasan dalam rumah tangga merupakan masalah sosial sekaligus bersifat sensitif, diantara penyebabnya adalah: pertama, kekerasan dalam rumah tangga memiliki ruang lingkup yang relatif tertutup dan bersifat pribadi, karena persoalannya terjadi dalam lingkup keluarga. Kedua, kekerasan dalam rumah tangga sering kali dianggap wajar karena diyakini bahwa sebagai pemimpin dan kepala rumah tangga suami memperlakukan istri sekehendaknya adalah merupakan 
hadis tentang larangan memukul isteri ? (2) bagaimana status sanad pada hadis larangan memukul isteri yang di riwayatkan Abu Dawud?

\section{B. METODE}

Metode yang peneliti gunakan untuk mentakhrij adalah mencari salah satu lafal matan hadis. Kitab yang penulis gunakan adalah $M u$ 'jam al-Mufahras li Alfaz al-Hadis alNabawi karangan A.J. Wensinck dengan judul asli Concordance at Indices de la Tradition Musulmane yang diterjemahkan oleh Muhammad Fu'ad 'Abd al-Baqi. Kata yang akan penulis lacak adalah kata yang "لا تضربوا semakna dengan kalimat selanjutnya penulis mencari salah satu lafal matan hadis tersebut pada kitab Mu'jam al-Mufahras li Alfaz al-Hadis al-Nabawi, dengan mengembalikan pada kata dasar dari kata yang ingin dicari yaitu ضرب . Selanjutnya peneliti mencari kata tersebut sesuai dengan urutan abjad huruf hijaiyyah pada kitab Mu'jam al-Mufahras.

C. PEMBAHASAN

1. Redaksi Matan (teks) Hadis Larangan Memukul Isteri

Setelah melakukan penelusuran dengan metode diatas, hasil yang penulis didapatkan adalah sebagaimana berikut:

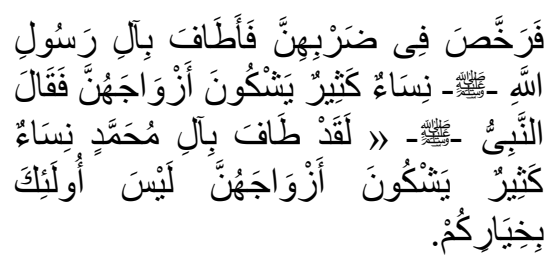

Rasulullah saw. bersabda: janganlah kalian memukul hambahamba perempuan Allah (isteriisteri). Maka datanglah Umar bin Khattab pada Nabi Muhammad saw. Umar berkata para isteri sudah berbuat durhaka pada suaminya. Lalu Nabi pun memberikan dispensasi untuk memukul mereka. Setelah itu, banyak isteri berkeliling di keluarga Rasulullah seraya mengadukan suami-suami mereka. Nabi Muhammad kemudian bersabda, sungguh banyak isteri berkeliling pada keluarga Muhammad mengadukan suamisuami mereka, mereka bukanlah orang yang terbaik di antara kalian"

Berdasarkan hadis diatas dapat di ketahui bahwa Nabi melarang memukul isteri dan jika suami ringan tangan dalam memukul isteri maka dia bukan suami yang terbaik.

Sikap Nabi berdasarkan hadis yang di riwayat Abu Dawud diatas sangat menarik untuk dikaji, sebab diawal Nabi melarang untuk memukul isteri, kemudian membolehkannya ketika terindikasi Nusyuz, kemudian memberi penilaian yang tidak baik terhadap suami yang ringan tangan terhadap istrinya. Oleh sebab itu peneliti tertarik untuk meneliti status hadis larangan memukul isteri dalam tinjauan takhrij hadis. Pada penelitian ini akan

menjawab dua persoalan penting dalam kajian takhrij hadis yaitu; (1) kitab apa saja yang meriwayatkan redaksi matan (teks) 


\begin{tabular}{|c|c|c|c|c|}
\hline No & Lafal & Riwayat & Bab & Bagian ke \\
\hline 1 & لا تضربن إماء الله & Ibn Majah & Nikah & 51 \\
\hline \multirow{2}{*}{2} & \multirow{2}{*}{ لا تضربوا إماء الله } & Abu Dawud & Nikah & 42 \\
\hline & & Ad-Darimi & Nikah & 34 \\
\hline
\end{tabular}

berkata: telah mengelilingi keluarga Muhammad 70 orang perempuan, setiap mereka mengadukan suaminya. Mereka bukanlah orang yang terbaik di antara kalian"

2) Hadis riwayat Abu Dawud pada bab fi dharbi an-Nisa hadis no. 2148

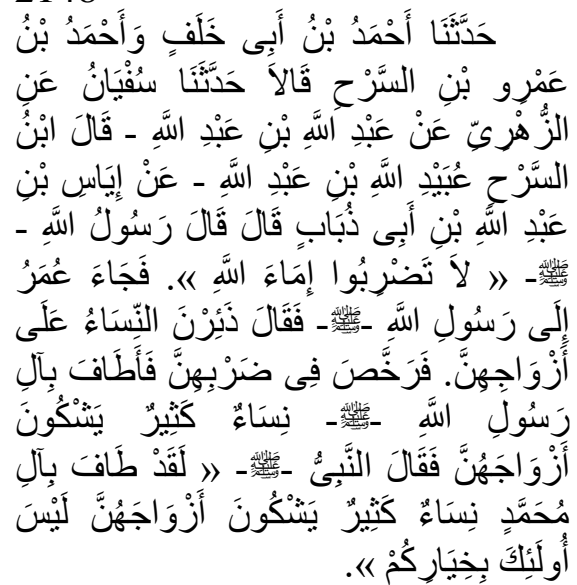

Ahmad bin Abi Khalaf dan Ahmad bin 'amr bin as-Sarh bercerita kepada kami, Sufyan bercerita kepada kami dari az-Zuhri dari 'Abdillah bin 'Abdillah, "Ibn as-Sarh berkata 'Ubaidillah bin 'Abdillah" dari Iyas bin 'Abdillah bin Abi Dzubab, Rasulullah saw. bersabda: janganlah kalian memukul hambahamba perempuan Allah (isteriisteri). Maka datanglah Umar bin Khattab pada Nabi Muhammad saw. Umar berkata para isteri sudah berbuat durhaka pada suaminya. Lalu Nabi pun memberikan dispensasi untuk memukul mereka. Setelah itu, banyak isteri berkeliling di keluarga Rasulullah seraya mengadukan suami-suami mereka. Nabi Muhammad kemudian
Berdasarkan informasi al-mu'jam, matan hadis larangan memukul istri terdapat dalam beberapa kitab yaitu pada kitab Sunan Ibn Majah, Sunan Abu Dawud, dan Sunan ad-Darimi. Setelah merujuk sumber kitab asli, berikut peneliti sajikan matan hadis dan terjemahannya:

1) Hadis Riwayat Ibn Majah pada bab dharbu an-nisa, hadis no. 1985

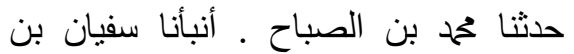

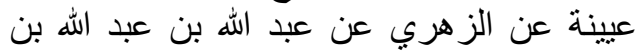
عمر عن إياس بن عبد الله بن أبي ذباب قال بال: -

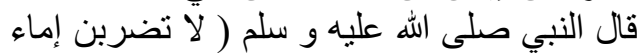
الله ) فجاء عمر إلى النبي صلى الله اله عليه و سلم اله

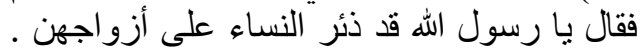

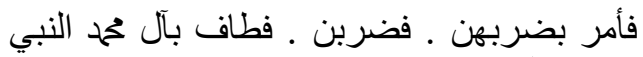

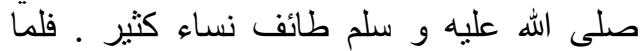

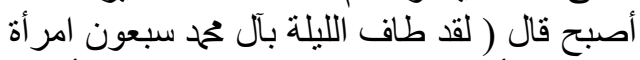
ـ كل امرأة تشتكي زوجها ـ فلا تجدون أولئك الكال خياركم ) .

Muhammad bin as-Shabah bercerita kepada kami, Sufyan bin 'Uyainah mengabarkan kepada kami dari az-Zuhri dari 'Abdillah bin 'Abdillah bin 'Umar dari Iyas bin 'Abdillah bin Abi Dzubab, Rasulullah saw. bersabda: janganlah kamu memukul hamba-hamba perempuan Allah (isteri-isteri). Maka datanglah Umar bin Khattab pada Nabi Muhammad saw. Umar berkata sungguh para isteri sudah berbuat durhaka pada suaminya. Lalu Nabi pun memberikan memerintahkan untuk memukul mereka. Maka kami memukul mereka Setelah itu, banyak isteri berkeliling di keluarga Rasulullah. Ketika pagi hari Nabi 
shahih terkadang tidak terlepas dari kecacatan. Hal ini bisa dilihat dari redaksi matan hadis yang satu dengan hadis yang lainnya.

Berdasarkan tiga matan (teks) hadis tentang larangan memukul istri dalam riwayat Sunan Ibn Majah, Sunan Abu Dawud, dan Sunan adDarimi. Peneliti menemukan unsur ilal (penyakit/cacat) pada matan yang diriwayatkan Ibnu Majah. Matan hadis dalam riwayat Ibnu Majah disebutkan tambahan keterangan mengenai waktu dan jumlah para istri yang berdemo kepada Nabi. Pada riwayat Ibnu Majah disebutkan; para demonstran datang pada Nabi pada waktu malam hari, kemudian baru pagi hari Nabi bercerita. Selain itu juga menyebutkan jumlah istri yang menemui beliau yaitu sebanyak 70 orang istri. Setiap dari mereka mengadukan pemukulan suami mereka masing-masing. Kemudian di riwayat dalam Ibnu Majah juga disebut kata fa'mur bi dharbihinna padahal dalam dua riwayat lainnya yaitu riwayat $\mathrm{Abu}$ Dawud dan riwayat ad-Darimi diredaksikan dengan farakhasha fi dharbihinna. Dua redaksi yang berbeda tersebut menurut penulis mempunyai maksud dan makna yang berbeda. Kata fa'mur mengandung makna; Nabi menyuruh tanpa adanya sisi keberatan pada diri Nabi atau bisa dibilang memberikan kebebasan secara mutlak. Sedangkan kata farakhasha mengandung makna; Nabi memberikan perintah dengan adanya rasa sedikit keberatan dan memberikan batasan.

Peneliti menilai adanya ilal pada matan hadis riwayat Ibnu Majah, karena semua rawi terakhir berasal dari rantai transmisi hadis bersumber bersabda, sungguh banyak isteri berkeliling pada keluarga Muhammad mengadukan suamisuami mereka, mereka bukanlah orang yang terbaik di antara kalian"

3) Hadis riwayat ad-Darimi pada bab fi an-Nahyi 'an Dhorbi anNisa hadis no. 2219

$$
\begin{aligned}
& \text { أخبرنا تحمد بن أحمد بن أبي خلف حدثنا }
\end{aligned}
$$

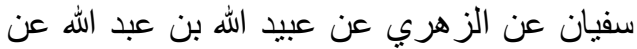

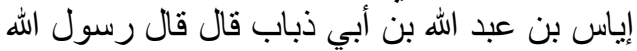

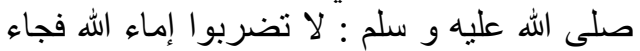

$$
\begin{aligned}
& \text { عمر بن الخطاب إلى رسول الله صلى الله عليه و لهاه }
\end{aligned}
$$

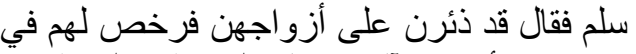

Muhammad bin Ahmad bin Abi Khalaf bercerita kepada kami, Sufyan bercerita kepada kami dari az-Zuhri dari 'Ubaidillah bin 'Abdillah, dari Iyas bin 'Abdillah bin Abi Dzubab berkata: Rasulullah saw. bersabda: janganlah kalian memukul hamba-hamba perempuan Allah (isteri-isteri). Maka datanglah Umar bin Khattab pada Nabi Muhammad saw. Umar berkata sungguh para isteri sudah berbuat durhaka pada suaminya. Lalu Nabi pun memberikan dispensasi untuk memukul mereka. Setelah itu, banyak isteri berkeliling di keluarga Rasulullah seraya mengadukan suami-suami mereka. Nabi Muhammad kemudian bersabda, sungguh banyak isteri berkeliling pada keluarga Muhammad mengadukan suami-suami mereka, mereka bukanlah orang yang terbaik di antara kalian"

Pembahasan tentang matan (teks) hadis. Hadis yang dinilai 
- لע : janganlah kalian memukul

- Hamba Allah (istri-istri)

- ذئرن النساء : Perempuan durhaka (nusyuz)

- : maka diberi hak, diperbolehkan

- يشكون : mereka mengadu

- ليس أولئك بخياركمن : bukanlah yang baik diantara kalian

\section{3) Terjemah}

Ahmad bin Abi Khalaf dan Ahmad bin 'amr bin as-Sarh bercerita kepada kami, Sufyan bercerita kepada kami dari az-Zuhri dari 'Abdillah bin 'Abdillah, "Ibn asSarh berkata 'Ubaidillah bin 'Abdillah" dari Iyas bin 'Abdillah bin Abi Dzubab, Rasulullah saw. bersabda: janganlah kalian memukul hamba-hamba perempuan Allah (isteri-isteri). Maka datanglah Umar bin Khattab pada Nabi Muhammad saw. Umar berkata para isteri sudah berbuat durhaka pada suaminya. Lalu Nabi pun memberikan dispensasi untuk memukul mereka. Setelah itu, banyak isteri berkeliling di keluarga Rasulullah seraya mengadukan suami-suami mereka. Nabi Muhammad kemudian bersabda, sungguh banyak isteri berkeliling pada keluarga Muhammad mengadukan suamisuami mereka, mereka bukanlah orang yang terbaik di antara kalian" (dari atas) dari Iyas bin Abdullah kepada Ubaidillah dan Abdullah bin Abdullah bin Umar kepada Zuhri kepada Sufyan. Sehingga secara logika tidak mungkin terjadi perbedaan redaksi matan hadis yang bersumber dari Sufyan. Dengan demikian, harusnya Muhammad bin al-Shabah (rawi terakhir dari Ibnu Majah) menyampaikan hadis yang serupa dengan Ahmad bin Abi Khalaf, Ahmad bin Amr bin Sarh (rawi Abu Dawud) dan Muhammad bin Ahmad bin Abi Khalaf (rawi Darimi). Namun dibalik itu semua memungkinkan juga riwayat ini diredaksikan bi al-Ma'na.

\section{Status Sanad Hadis Larangan Memukul Istri}

1) Redaksi Hadis Riwayat Abu Dawud pada bab fi dharbi anNisa hadis no. 2148.

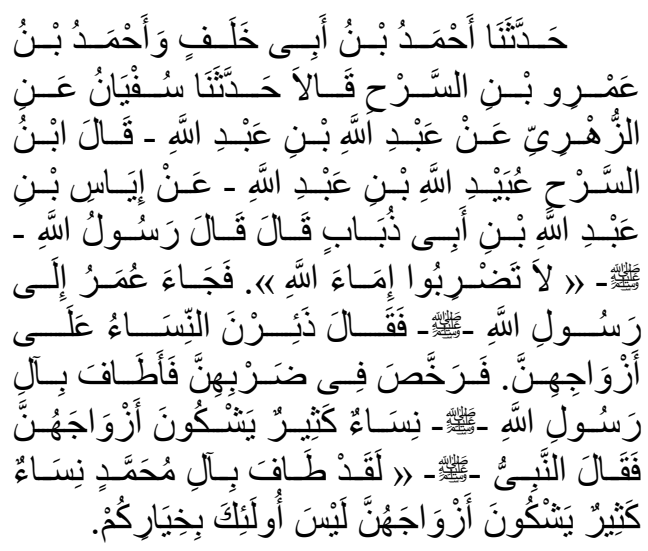

2) Mufradat

\section{4) I'tibar Sanad}

\begin{tabular}{|c|c|c|c|}
\hline No & $\begin{array}{c}\text { Nama } \\
\text { Periwayat }\end{array}$ & $\begin{array}{c}\text { Urutan } \\
\text { Sebagai } \\
\text { Periwayat } \\
\end{array}$ & $\begin{array}{c}\text { Urutan } \\
\text { Sebagai } \\
\text { Sanad } \\
\end{array}$ \\
\hline 1 & Iyas & Periwayat I & Sanad V \\
\hline 2 & - 'Ubaidillah bin & Periwayat II & Sanad IV \\
\hline
\end{tabular}




\begin{tabular}{|c|c|c|c|}
\hline & $\begin{array}{c}|c| \\
\text { 'Abdillah } \\
\text { 'Abdullah bin } \\
\text { 'Abdillah }\end{array}$ & Periwayat II & Sanad IV \\
\hline 3 & az-Zuhri & Periwayat III & Sanad III \\
\hline 4 & Sufyan & Periwayat IV & Sanad II \\
\hline 5 & $\begin{array}{c}\text { Ahmad bin 'amr } \\
\text { bin as-Sarh }\end{array}$ & Periwayat V & Sanad I \\
\hline Khalaf bin Abi & Periwayat V & Sanad I \\
\hline 6 & $\begin{array}{c}\text { Abu Dawud } \\
\text { Phakârij al- } \\
\text { Hadîts }\end{array}$ \\
\hline
\end{tabular}

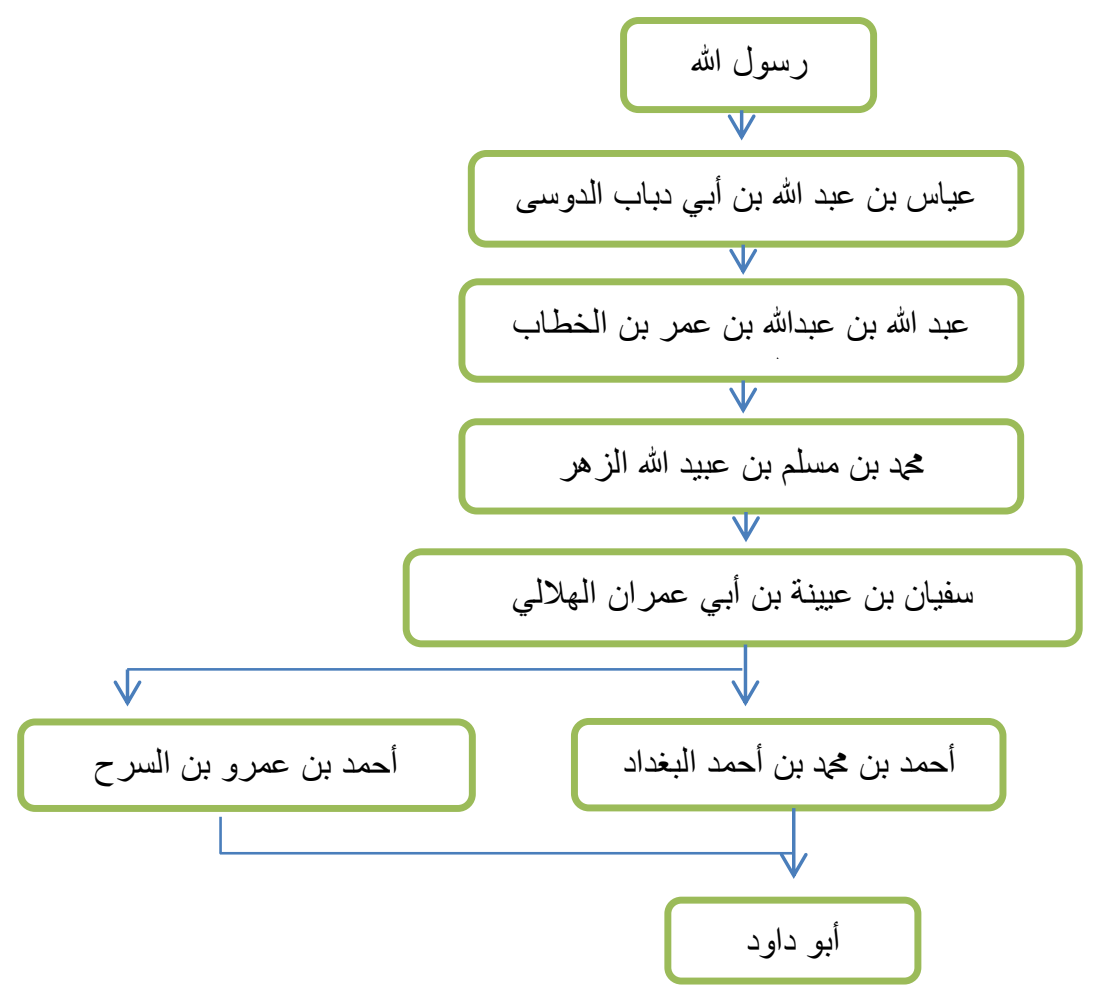

Al-Mizi dalam Tahdzib al-Kamal menyebut guru dari Iyas adalah Nabi saw. adapun muridnya adalah Abdullah dikatakan juga ('Ubaidillah bin 'Umar bin al-Khattab).

\section{II. 'Ubdullah bin 'Abdillah}

Nama lengkapnya adalah 'Abdullah bin 'Abdillah bin 'Umar bin al-Khattab. Gelar panggilannya adalah Abu Abdurrahman. Dia dinisbahkan dengan al-'Udwi. Wafat tahun 184 Hijriah.

\section{5) Sekilas Tentang Perawi}

\section{Iyas}

Nama lengkapnya adalah Iyas bin 'Abdillah bin Abi Dubab Ad-Dusi. Berasal dari Mekkah. Peneliti tidak mendapati refrensi tentang tahun kelahiran dan tahun wafatnya.

'Ulama memperselisihkan tentang statusnya dari golongan sahabat Nabi saw. diantara yang menyebut demikian adalah Adz-Dahabi, AlMizi dalam kitab Tahdzib al-Kamal dan Ibnu Hajar dalam kitab Taqrib. 


\section{Sufyan}

Nama lengkapnya adalah Sufyan bin 'Uyainah bin abi 'Imron. Nama panggilannya adalah Abu Muhammad, dinisbahkan dengan kufi, tergolong Thabaqah ke 20 tahun 191 sampai tahun 200 Hijriyah, wafat tahun 198 Hujriyah.

Abu Muhammad dikenal sebagai orang yang al-a'lam dan Tsiqqoh sebagaimana disebut adz-Dzahabi dalam al-Kasyaf, demikian juga dengan Ibn Hajar dalam Taqrib.

Guru-guru Sufyan diantaranya adalah Ibrohim bin 'Uqbah, Ibrohim bin Muslim al-Hajri, Ayub bin Musa, 'Ashim bin 'Abdillah, Muhammad bin Muslim bin Syihab az-Zuhri, dan yang lainnya. Murid-muridnya diantaranya adalah Ibrohim bin Bisyar ar-Ramadi, Ahmad bin Hanbal, Abu Ath-Thohir Ahmad bin 'Amr bin As-Sarh al-Mishri.

\section{V. -Ahmad bin 'amr bin as-Sarh}

Nama lengkapnya adalah Ahmad bin 'Amr bin 'Abdillah bin 'Amr bin as-Sarh. Lebih dikenal dengan nama Abu ath-Thohir Ibn asSarh, nama panggilannya adalah Abu Thohir, dinisbahkan dengan alQurosyi, tergolong thobaqah ke 25 tahun 241 sampai tahun 250 Hijriyah, wafat tahun 250 Hijriyah.

Abu ath-Thohir Ibn as-Sarh, dikenal sebagai orang yang tsiqqoh sebagaimana disebut Ibnu Hajar dalam Taqrib, an-Nasa'I juga menyebut sebagai orang yang tsiqqoh.

Guru-guru Abu ath-Thohir Ibn as-Sarh diantaranya adalah Sufyan bin 'Uyainah, Asyhab bin 'abdul 'Aziz, 'Abdullah bin Wahab, dan yang lainnya. Murid-muridnya
'Abdullah bin 'Abdillah dinilai oleh 'Ulama sebagai orang yang tsiqqoh, diantara yang menyatakannya adalah Ibnu Hajar dalam kitab Taqrib, Abu Zur'ah, dan an-Nasa'i. Adz-Dzahabi dalam alKasyaf menilainya sebagai orang yang suduq. Menurut Ibn Hibban pada kitab ats-tsiqat dia adalah orang yang zuhud dizamannya.

Guru dari 'Abdullah bin 'Abdillah diantaranya adalah Iyas bin Abdillah bin Abi Dubab, Abdullah bin 'Umar, Abu Hurairah dan lainnya. Muridmuridnya diantaranya adalah Said bin Abdirrahman bin Wa'il alAnshari, Abdurrahman bin Harits bin Iyas bin Abi Rubi'ah, Muhammad bin Muslim bin Syihab az-Zuhri, dan yang lainnya.

\section{III. az-Zuhri}

Nama lengkapnya adalah
Muhammad bin Muslim bin 'Ubaidillah bin 'Abdillah bin Shihab bin 'Abdillah bin Harits bin Zuhri. Lebih dikenal dengan nama Ibn Syihab az-Zuhri, nama panggilannya adalah Abu Bakar. Dia dinisbahkan dengan Qurasyi, tergolong thabaqah ke 13 tahun 121 sampai 130 Hijriyah. Wafat tahun 125 Hijriyah.

Ibn Syihab az-Zuhri dikenal sebagai orang yang al-a'lam sebagaimana disebut adz-Dzahabi dalam al-Kasyaf, sedangkan Ibn Hajar dalam Taqrib menyebutnya sebagai orang yang faqih dan hafidz.

Guru dari az-Zuhri diantaranya adalah 'Ubaidillah bin 'Abdillah bin 'Umar bin al-Khattab, umar bin 'Abdul 'Aziz, Mahmud bin ar-Rabi', dan yang lainnya. Murid-muridnya diantaranya adalah Tsabit bin Tsauban, Sufyan bin 'Uyainah, Sofwan bin Salim. 
'Abdillah bin Sulaiman, dan yang lainnya.

\section{Abu Dawud}

Nama lenggkap adalah Sulaiman bin al-Asy'as bin Ishaq bin Basyir bin Syidad bin 'Amr al-Azi asSijistani, lahir tahun 202 Hijriyah di Sijistan. Wafat dibasrah 16 Syawal 275 Hijriyah/889 Masehi. Gurugurunya antara lain; Ahmad bin Hanbal al-Qan'abi, Abu 'Amr adDarir, Muslim bin Ibrahim dan lainnya. Murid-muridnya antara lain Abu Isa at-Tirmizi, Abu Abd Rahman an-Nasa'I, Abu bakar bin Abu dawud, Abu Bakar bin Dassah, dan yang lainnya.

\section{6) Kritik Sanad dan Status Hadis}

Ke-muttashil-an (bersambungnya) sanad hadis di atas dapat dilihat pada tabel berikut: diantaranya adalah Muslim, Abu Dawud, Nasa'I, Ibn Majah, dan yang lainnya.

\section{-Ahmad bin Abi Khalaf}

Nama lengkapnya adalah Ahmad bin Muhammad bin Ahmad bin Muhammad bin Khalaf. Dinisbahkan dengan al-Bagdadi, tergolong thobaqoh ke 24 tahun 131 sampai tahun 240 Hijriyah, wafat tahun 233 hijriyah.

Ibn Hajar dalam taqrib menyatakan Ahmad bin Muhammad adalah sebagai orang yang tsiqqoh, demikian juga dengan Abu Syaibah.

Guru-guru Ahmad bin Muhammad diantaranya adalah Husain bin 'Umar al-Ahmasi, Sufyan bin 'Uyainah, abi Ibad bin Ibad Yahya al-Bashori, dan yang lainnya. Murid-muridnya adalah Abu Dawud as-Sajastani, Abu Syaibah Ibrohim bin Abi Bakr, Muhammad bin

\begin{tabular}{|c|c|c|c|c|c|c|c|c|}
\hline $\begin{array}{l}\mathbf{N} \\
\mathbf{o}\end{array}$ & $\begin{array}{c}\text { Nama } \\
\text { Periway } \\
\text { at }\end{array}$ & Kunyah & Lahir & $\begin{array}{l}\text { Waf } \\
\text { at }\end{array}$ & Guru & Murid & Lam-bang & $\begin{array}{c}\text { Kete } \\
\text { rang } \\
\text { an }\end{array}$ \\
\hline 1 & $\begin{array}{c}\text { Abu } \\
\text { Dawud }\end{array}$ & $\begin{array}{c}\text { Abi Dawud } \\
\text { Sulaiman bin al- } \\
\text { asy'ats as-sajastani }\end{array}$ & $202 \mathrm{H}$ & $\begin{array}{c}275 \\
\mathrm{H}\end{array}$ & $\begin{array}{l}\text { Muslim bin } \\
\text { Ibrahim }\end{array}$ & $\begin{array}{c}\text { Abu Abd Rahman } \\
\text { an-Nasa'I }\end{array}$ & حدثنا & منصل \\
\hline 2 & $\begin{array}{l}\text { Ahmad } \\
\text { bin Abi } \\
\text { Khalaf }\end{array}$ & - & - & $\begin{array}{c}233 \\
\mathrm{H}\end{array}$ & $\begin{array}{l}\text { Sufyan bin } \\
\text { 'Uyainah }\end{array}$ & $\begin{array}{c}\text { Abu Dawud as- } \\
\text { Sajastani }\end{array}$ & حدثنا & متصل \\
\hline & $\begin{array}{l}\text { Ahmad } \\
\text { bin 'amr } \\
\text { bin as- } \\
\text { Sarh }\end{array}$ & Abu Thohir & - & $\begin{array}{c}250 \\
\mathrm{H}\end{array}$ & $\begin{array}{l}\text { Sufyan bin } \\
\text { 'Uyainah }\end{array}$ & $\begin{array}{c}\text { Abu Dawud as- } \\
\text { Sajastani }\end{array}$ & عن & متصلة \\
\hline 3 & Sufyan & Abu Muhammad & - & $\begin{array}{c}198 \\
\mathrm{H}\end{array}$ & $\begin{array}{l}\text { Muhammad bin } \\
\text { Muslim bin } \\
\text { Syihab az-Zuhri }\end{array}$ & $\begin{array}{c}\text { Abu Ath-Thohir } \\
\text { Ahmad bin 'Amr } \\
\text { bin As-Sarh al- } \\
\text { Mishri }\end{array}$ & عن & منقة \\
\hline 4 & az-Zuhri & Abu Bakar & & $\begin{array}{c}125 \\
\mathrm{H}\end{array}$ & $\begin{array}{l}\text { 'Ubaidillah bin } \\
\text { 'Abdillah bin } \\
\text { 'Umar bin al- } \\
\text { Khattab }\end{array}$ & $\begin{array}{l}\text { Sufyan bin } \\
\text { 'Uyainah }\end{array}$ & 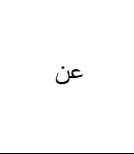 & متصل \\
\hline 5 & $\begin{array}{l}\text { 'Abdullah } \\
\text { bin } \\
\text { 'Abdillah }\end{array}$ & Abu Abdurrahman & - & $\begin{array}{c}184 \\
\mathrm{H}\end{array}$ & $\begin{array}{l}\text { Iyas bin Abdillah } \\
\text { bin Abi Dubab }\end{array}$ & $\begin{array}{l}\text { Muhammad bin } \\
\text { Muslim bin } \\
\text { Syihab az-Zuhri }\end{array}$ & عن & | منصلة \\
\hline
\end{tabular}


Norcahyono. 2019. Larangan Memukul Istri dalam Kajian Hadis

\begin{tabular}{|c|c|c|c|c|c|c|c|c|}
\hline & $\begin{array}{l}\text { 'Ubaidilla } \\
\text { h bin } \\
\text { 'Abdillah }\end{array}$ & - & - & - & - & - & - & أله ألخ عبد الهد \\
\hline 6 & Iyas & $\begin{array}{c}\text { 'Iyas bin 'Abdillah } \\
\text { bin 'Abi Dubab ad- } \\
\text { Dusi }\end{array}$ & - & - & Rasulullah & $\begin{array}{l}\text { Abdullah } \\
\text { dikatakan juga } \\
\text { ('Ubaidillah } \\
\text { bin 'Umar bin } \\
\text { al-Khattab). }\end{array}$ & قال & $\begin{array}{c}\text { Dipe } \\
\text { rselis } \\
\text { ihka } \\
\mathrm{n} \\
\text { dari } \\
\text { golo } \\
\text { ngan } \\
\text { saha } \\
\text { bi }\end{array}$ \\
\hline
\end{tabular}


tsiqqoh,perselisihan ini tidak ada masalah.

\section{Kesimpulan dan Saran}

Berdasarkan metode takhrij yang peneliti gunakan, Hadis larangan memukul isteri terdapat dalam tiga buah kitab, yaitu: dalam Kitab Sunan Ibn Majah pada bab dharbu an-nisa, hadis no. 1985, Kitab Sunan Abu Dawud pada bab fi dharbi an-Nisa hadis no. 2148, dan Kitab Sunan adDarimi pada bab fi an-Nahyi 'an Dhorbi an-Nisa hadis no. 2219.

Adapun status sanad pada hadis larangan memukul isteri yang di riwayatkan Abu Dawud berdasarkan hasil penelitian sebagai berikut:

1. Perawi kedua sampai ke lima pada hadis yang dibahas semua muttasil dan tsiqqoh.

2. Iyas sebagai periwayat pertama diperselisihkan tentang status kesahabatannya, namun pendapat yang lebih kuat menurut Ibnu Hajar, Ibn Hibban, al-Hakim dan adz-Dzahabi Iyas tergolong sebagai sahabi.

3. Jika Iyas digolongkan sebagai tabi'in hadis ini berstatus mursal.

Karena Iyas secara tidak langsung mengambil riwayat dari Nabi tanpa menyebutkan sahabat yang meriwayatkan hadis.

4. Jika Iyas digolongkan sebagai sahabat (junior) maka hadisnya berstatus mursal sahabi.

5. Berdasarkan 'itibar sanad dan Iyas dihukumi sebagai sahabi maka hadis ini adalah gharib.

6. Menurut al-Bani, sanad hadis yang penulis teliti adalah sahih.

Menilai status hadis tidaklah mudah, haruslah merujuk kepada
Tabel diatas adalah rincian sanad dan penilaian yang peneliti gambarkan, adapun status hadis yang penulis temukan adalah sebagaimana berikut;

a. Iyas sebagai periwayat pertama diperselisihkan tentang status kesahabatannya.

b. Jika Iyas digolongkan sebagai tabi'in hadis ini berstatus mursal.

Karena iyas secara tidak langsung mengambil riwayat dari Nabi tanpa menyebutkan sahabat yang meriwayatkan hadis.

c. Jika Iyas digolongkan sebagai sahabat (junior) maka hadisnya berstatus mursal sahabi.

d. Berdasarkan 'itibar sanad dan Iyas dihukumi sebagai sahabi maka hadis ini adalah gharib.

e. Perawi kedua sampai ke lima pada hadis diatas semua muttasil dan tsiqqoh.

Catatan diatas adalah hasil kesimpulan tentang status hadis yang peneliti teliti. Menurut al-Bani, sanad hadis yang peneliti teliti berstatus sahih. Adapun Iyas sebagai perawi pertama yang masih diperselisihkan tentang statusnya sebagai sahabi menurut Imam Hafidz Ibnu Hajar pendapat yang kuat adalah Iyas tergolong sebagai sahabi. Ibn Hibban, al-Hakim dan adz-Dzahabi juga menilai hadis ini adalah sahih.

Al-Bani menilai sanad hadis ini adalah sahih karena seluruh perawinya adalah tsiqqoh, namun terkait permasalahan yang diyakini Ahmad bin Abi Khalaf adalah Abdullah dan Ibn Sarh adalah 'Ubaidullah, mereka adalah putra Abdullah bin 'Umar bin al-Khattab mereka

sama-sama 
ahlinya, dengan demikian

mengamalkan sebuah hadis.

\section{DAFTAR PUSTAKA}

Abi Dawud Sulaiman bin al-asy'ats as-sajastani, Sunan Abi Dawud, Tahqiq: Syu'aib ar-Na'uth dan Muhammad Kamal, Jilid 3, (Dar ar-Risalah, 2009)

Abu Abdillah al Qazwaini, Muhammad bin Yazid. Sunan Ibnu Majah, Jilid I, (Bairut: Dar al Fikr, t.th)

Abi Dawud Sulaiman bin al-asy'ats as-sajastani, Sunan Abi Dawud, (al-Nasr wa al-Tauzi': Dar al-Fiqr al-Juz'u ats-Tsani, t.th)

Abu Muhammad ad-Darimi, Abdullah bin Abdurrahman. Sunan ad-Darimi, cet. 1, (Bariut: Dar al-kitab al-'Arobi, 1407)

Anshori S, Dadang Enkos Kosasih dan Farida sarimaya. Membincangkan Feminisme, (Bandung: Pustaka Hidayah, 1977)

Abu Syuhbah, Muhammad Muhammad. Kitab Hadis Sahih yang Enam, Terj. Maulana Hasanuddin, (Jakarta: Pustaka lentera Antanusa, 1991)

al-Bani, Muhammad Nasiruddin. Sahih Abi Dawud, cet. 1, Jilid 6, (Kuwait: muasasah gharas linnasr wa at-tauzi', 2002)

al-Mizi, Yusuf bin Az-Zaki Abdurrahman Abu al-Hujaj. Tahdzib al-Kamal, tahqiq; Bisyar 'Uwad Ma'ruf jilid 3, (Bairut: Muassasah ar-Risalah, 1980)

CD Mausu`ah al-Hadîts al-Syarif, al-Ishdar al-Tsani 2.00 (Global Islamic Software Company, 1991-1997).

Fakih, Mansour. (ed.) Analisis Gender \& transformasi Sosial, (Yogyakarta: Pustaka Pelajar, 2001)

Wensinck, A.J. Mu'jam al-Mufahras li Alfaz al-Hadis al-Nabawi, Juz III (Leiden: Maktabah Baril, 1936 M) 